University of Nebraska - Lincoln

DigitalCommons@University of Nebraska - Lincoln

10-1969

\title{
Genetic Studies of Induced Mutants in Melilotus alba. I. Short- Internode Dwarf, Curled Leaf, Multifoliolate Leaf, and Cotyledonary Branching
}

B. G. Gengenbach

Francis A. Haskins

University of Nebraska-Lincoln, fhaskins@neb.rr.com

H. J. Gorz

Follow this and additional works at: https://digitalcommons.unl.edu/agronomyfacpub

Part of the Plant Sciences Commons

Gengenbach, B. G.; Haskins, Francis A.; and Gorz, H. J., "Genetic Studies of Induced Mutants in Melilotus alba. I. Short-Internode Dwarf, Curled Leaf, Multifoliolate Leaf, and Cotyledonary Branching" (1969).

Agronomy \& Horticulture -- Faculty Publications. 293.

https://digitalcommons.unl.edu/agronomyfacpub/293

This Article is brought to you for free and open access by the Agronomy and Horticulture Department at DigitalCommons@University of Nebraska - Lincoln. It has been accepted for inclusion in Agronomy \& Horticulture -Faculty Publications by an authorized administrator of DigitalCommons@University of Nebraska - Lincoln. 


\title{
Genetic Studies of Induced Mutants in Melilotus alba. I. Short-Internode Dwarf, Curled Leaf, Multifoliolate Leaf, and Cotyledonary Branching ${ }^{1}$
}

\author{
B. G. Gengenbach, F. A. Haskins, and H. J. Gorz ${ }^{2}$
}

\begin{abstract}
Information obtained from the $F_{1}, F_{2}$, and $F_{3}$ generations of crosses between the normal annual $M$. alba progenitor line and the four mutants, short-internode dwarf, curled leaf, multifoliolate leaf, and cotyledonary branching, indicates that each character is conditioned by a single pair of alleles. The multifoliolate leaf character is dominant over the normal phenotype; the other three mutant characters are recessive. The symbols $d w$, $c l, M f$, and $c b$ are proposed as designations for the respective mutant genes.
\end{abstract}

Additional index word: Sweetclover.

TNHERITANCE studies in white-flowered sweet1 clover, Melilotus alba Desr., have dealt with a relatively small number of mutations, most of which occurred spontaneously. The 1965 review of Smith and Gorz (10) lists only 19 mutant traits for which the mode of inheritance has been elucidated. Since 1965 an additional mutant gene, responsible for the unifoliolate leaf-cauliflower inflorescence phenotype, has been reported by Goplen (3). The need for added genetic markers in this species is obvious.

Within the past 15 years several workers have succeeded in isolating new mutant strains of $M$. alba following the use of ionizing radiation or chemical mutagens. Mutagenic work on this species was started in the early 1950's when Micke (7) began a series of experiments in which dry seeds were irradiated with $\mathrm{X}$ rays or thermal neutrons. From this and other studies of Micke and of Scheibe and Hülsmann (8), who utilized chemical mutagens, some 690 independently occurring mutations had been identified by 1966 (9). Very few of these mutants have been subjected to genetic analysis.

${ }^{1}$ Contribution from the Crops Research Division, Agricultural Research Service, U. S. Department of Agriculture, and the Nebraska Agricultural Experiment Station, Lincoln, Nebr. Supported in part by the National Science Foundation (Grant No. GB-1148). Published with the approval of the Director as Paper No. 2521, Journal Series, Nebraska Agr. Exp. Sta. Most of the data were taken from a thesis submitted by the senior author to the University of Nebraska in partial fulfillment of the requirements for the M. Sc. degree. Received March 3, 1969.

${ }^{2}$ Formerly Graduate Assistant in Agronomy, University of Nebraska, (now graduate student in the Agronomy Department, University of Illinois); Bert Rodgers Professor of Agronomy, University of Nebraska, Lincoln 68503; and Research Geneticist, Crops Research Division, Agricultural Research Service, U. S. Department of Agriculture, Lincoln, Nebr., respectively.
A recent report from this laboratory (6) deals with the isolation of numerous mutants in an annual strain of $M$. alba in the second generation following treatment of seeds with ethyl methanesulfonate. The present paper deals with the inheritance of four of these mutants.

\section{MATERIALS AND METHODS}

All plants used in this study were derived from an annual strain of $M$. alba which originated as a plant introduction (P.I. $165,554)$ from India. Plants of this strain are relatively short in stature, autogamous, and have a short life cycle; hence they are well suited for culture in growth chambers. The plants were grown in chambers at $25 \mathrm{C}$ and approximately $70 \%$ relative humidity, with continuous cool white fluorescent light at about $1,000 \mathrm{ft}-\mathrm{c}$. Under these conditions normal plants attain a height of 35 to $50 \mathrm{~cm}$ and produce ripe seeds within about 8 weeks after planting. Branches, if present, are small in number and short in length. Leaves are trifoliolate with obovate, moderately serrated leaflets.

The induction and subsequent isolation of mutants have been described (6). The four mutant characters chosen for study are short-internode dwarf, curled leaf, multifoliolate leaf, and cotyledonary branching (Fig. 1). Plants for crossing with the normal annual $M$. alba parent were selected from $M_{4}$ lines of these mutants. These lines resulted from two generations of selfing following isolation of the mutants (three generations of selfing following treatment with the mutagen). Under growth chamber conditions the four mutant lines exhibit the following distinct phenotypes:

Short-internode dwarf plants have about the same number of nodes as normal plants, but they attain a height of only 5 to $10 \mathrm{~cm}$. Petiole length and leaflet size are reduced slightly. Plants do not branch; they typically appear very compact and sturdy.

Curled leaf plants are characterized by curled leaflets and twisted or curved stems, petioles, and flower parts. Leaflet edges curl up and toward the midrib, producing a canoe-shaped appearance. Random curvature of the stem, first in one direction for a short distance and then in another, tends to result in a semiprostrate growth habit. Petiole curvature is typically less pronounced than stem curvature. Filaments and styles are usually slightly twisted, and petal curvature is greater than normal.

Multifoliolate leaf plants have leaves composed of one to six leaflets of varying morphology, ranging from moderately to severely serrated, and from obovate or rectangular to mere bracts. The size, shape, and number of leaflets comprising one leaf vary considerably on a single plant. A few apparently normal trifoliolate leaves occur on some plants.

The cotyledonary branching mutant (also referred to as the branched mutant) is characterized by the formation of a single branch in the axil of each cotyledon. These branches from the cotyledonary node become visible 2 to 3 weeks after seedling emergence. Branches then develop sequentially up the stem from other leaf axils. The growth rate of this mutant is faster than normal for the first 2 weeks, but it decreases at about 


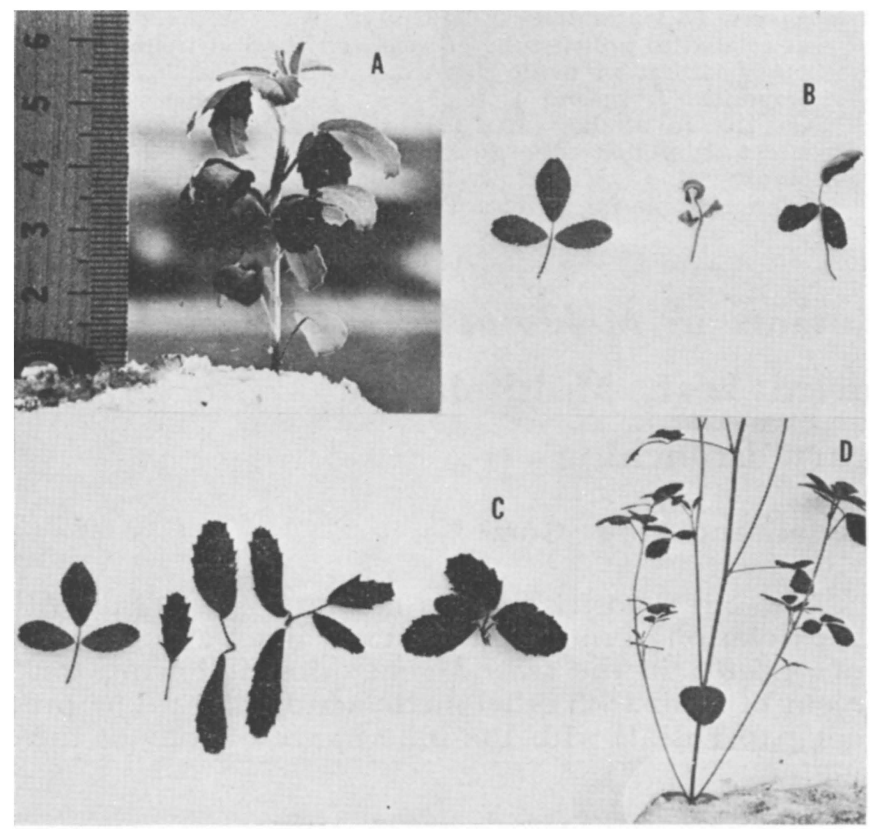

Fig. 1. (A) Short-internode dwarf plant 30 days after planting. (B) Leaf from a normal plant (left) and two leaves from a curled leaf plant. (C) Leaf from a normal plant (left) and four leaves from one multifoliolate leaf plant. (D) Basal portion of a cotyledonary branching plant 38 days after planting.

the time branching starts. Mature plants are shorter ( $1 / 2$ to $2 / 3$ as tall) and bushier than normal.

Plants were grown from hand-scarified seeds, planted in 1-pint plastic coated milk cartons filled with a mixture of vermiculite, soil, and sand (6:4:1 by volume), and covered with a $1-\mathrm{cm}$ layer of silica sand mixed with Orthocide ${ }^{3}$ (0.11 $\mathrm{g}$ Orthocide per liter of sand). The cartons were placed in plastic trays and watered by subirrigation. Parental, $F_{1}$, and $F_{2}$ lines were planted at the rate of five seeds per carton; $F_{3}$ lines were planted at the rate of nine seeds per carton.

Crosses between normal and mutant plants were made by first emasculating flower buds of the female parent, and then immediately pollinating these buds with pollen from the appropriate male parent. Reciprocal pollinations were made initially, but if and when several seeds had been obtained from a given cross, attempts to effect the reciprocal cross were abandoned.

Seeds obtained from each cross were planted, and the resulting $F_{1}$ plants were compared to plants of the parental lines with respect to morphology, general vigor, and seed set. $F_{1}$ plants were allowed to self-pollinate, and from each plant 115 seeds were planted to produce the $F_{2}$ generation. An exception to this procedure occurred in the case of two $F_{1}$ plants from the cross, normal $\times$ multifoliolate leaf, from which only 30 and 60 seeds were available for planting. Plants in the segregating $F_{2}$ populations were classified phenotypically. On the basis of the $F_{1}$ and $F_{2}$ data, a tentative hypothesis was formulated concerning the mode of inheritance of the mutant character. Chi-square $\left(\chi^{2}\right)$ tests were applied to the $F_{2}$ data for each family and, where applicable, for pooled families to determine whether the data fit the hypothesis. Heterogeneity $\chi^{2}$ values also were calculated.

Each tentative hypothesis was tested further in the $F_{3}$ generation. The progenies of several $F_{2}$ plants classified as recessive were planted to determine whether the putative recessive condition bred true, and the progenies of at least $20 \mathrm{~F}_{2}$ plants of the dominant phenotype also were checked for segregation. In this progeny testing, nine seeds of each recessive $F_{2}$ plant, and in most cases, 18 seeds of each dominant $F_{2}$ plant were planted

${ }^{3}$ Mention of a specific product is for identification only and does not imply endorsement by the U. S. Department of Agriculture. for observation. Chi-square tests were applied to the following: (a) distribution of normal and mutant plants in each segregating $\mathbf{F}_{3}$ family, (b) the pooled data for all segregating $\mathbf{F}_{3}$ families, (c) heterogeneity among the segregating $\mathbf{F}_{3}$ families, and (d) distribution of segregating and nonsegregating families from dominant $\mathbf{F}_{2}$ plants. Numbers were small (less than five) in some cases, particularly in the recessive class of some $F_{3}$ families, but no correction was applied in the calculation of $\chi^{2}$ values.

\section{RESULTS AND DISCUSSION}

\section{Short-Internode Dwarf}

Hybrid seeds were obtained from the cross, shortinternode dwarf $X$ normal, but none from the reciprocal cross. The three $F_{1}$ plants grown were phenotypically normal, indicating that the dwarf trait is recessive. The ratio of normal to short-internode dwarf plants in the $F_{2}$ generation was approximately 3:1 (Table 1). A single gene pair was proposed to explain the observed inheritance pattern, with normal completely dominant over the dwarf growth habit.

The $\mathrm{F}_{3}$ results supported this hypothesis. The frequencies of normal and dwarf plants in segregating $\mathrm{F}_{3}$ families fit a $3: 1$ ratio (Table 2); and a $2: 1$ ratio of segregating to nonsegregating $F_{3}$ families from normal $\mathrm{F}_{2}$ plants was observed (Table 3 ). The prog. enies of five dwarf $\mathrm{F}_{2}$ plants were all dwarf, as expected for a recessive character.

On the basis of these results, it was concluded that the short-internode dwarf character is indeed controlled by one gene pair with normal height completely dominant over dwarf. The symbols $D w$ and $d w$ are sug. gested for the dominant and recessive alleles, respec-

Table 1. Chi-square tests for goodness-of-fit to a 3:1 ratio for the distributions of normal and mutant plants in the $F_{2}$ generation of crosses between normal and mutant plants.

\begin{tabular}{|c|c|c|c|c|}
\hline \multirow[b]{2}{*}{ Statistic } & \multicolumn{4}{|c|}{ Mutant character } \\
\hline & $\begin{array}{c}\text { Short- } \\
\text { internode } \\
\text { dwarf }\end{array}$ & $\begin{array}{c}\text { Curled } \\
\text { leaf }\end{array}$ & $\begin{array}{c}\text { Multi- } \\
\text { foliolate } \\
\text { leaf }\end{array}$ & $\begin{array}{c}\text { Cotyledonary } \\
\text { branching }\end{array}$ \\
\hline $\begin{array}{l}\text { No. of families } \\
\text { Class distrib. (pooled) } \\
\text { Normal: Mutant }\end{array}$ & $\begin{array}{c}3 \\
203: 61\end{array}$ & $\begin{array}{c}3 \\
199: 74\end{array}$ & $\begin{array}{c}2 \\
17: 61\end{array}$ & $\begin{array}{c}1 \\
75: 28^{*}\end{array}$ \\
\hline $\begin{array}{l}\text { Sum of family } \chi^{2} \text { values } \\
\chi^{2} \text {, pooled data } \\
\text { P value }\end{array}$ & $\begin{array}{c}2.90 \\
0.51 \\
0.25<P<0.50\end{array}$ & $\begin{array}{c}1.94 \\
0.65 \\
0.25<P<0.50\end{array}$ & $\begin{array}{c}1.28 \\
0.43 \\
0.50<\mathrm{P}<0,75\end{array}$ & $\begin{array}{c}0.26 \\
0.50<P<0,75\end{array}$ \\
\hline $\begin{array}{l}\text { Heterogeneity } x^{2} \\
\text { P value }\end{array}$ & $\begin{array}{c}2.39 \\
0.25<\mathrm{P}<0.50\end{array}$ & $\begin{array}{c}1.29 \\
0.50<\mathrm{P}<0.75\end{array}$ & $\begin{array}{c}0.85 \\
0.25<P<0.50\end{array}$ & --. \\
\hline
\end{tabular}

Table 2. Chi-square tests for goodness-of-fit to a $3: 1$ ratio for the distributions of normal and mutant plants in the $F_{0}$ generation of crosses between normal and mutant plants.

\begin{tabular}{|c|c|c|c|c|}
\hline \multirow[b]{2}{*}{ Statistic } & \multicolumn{4}{|c|}{ Mutant character } \\
\hline & $\begin{array}{c}\text { Short- } \\
\text { internode } \\
\text { dwarf }\end{array}$ & $\begin{array}{c}\text { Curled } \\
\text { leaf }\end{array}$ & $\begin{array}{c}\text { Multi- } \\
\text { foliolate } \\
\text { leaf }\end{array}$ & $\begin{array}{c}\text { Cotyledonary } \\
\text { branching }\end{array}$ \\
\hline $\begin{array}{l}\text { No. of families } \\
\text { Class distrib. (pooled) } \\
\text { Normal: Mutant }\end{array}$ & $\begin{array}{c}15 \\
192: 50\end{array}$ & $\begin{array}{c}14 \\
134: 33\end{array}$ & $\begin{array}{c}17 \\
54: 148\end{array}$ & $\begin{array}{c}23 \\
284: 103\end{array}$ \\
\hline $\begin{array}{l}\text { Sum of family } \chi^{2} \text { values } \\
\chi^{2}, \text { pooled data } \\
\text { P value }\end{array}$ & $\begin{array}{c}12.66 \\
2.43 \\
0.10<\mathrm{P}<0.25\end{array}$ & $\begin{array}{c}8.02 \\
2.44 \\
0.10<\mathrm{P}<0.25\end{array}$ & $\begin{array}{c}13.20 \\
0.32 \\
0.50<\mathrm{P}<0.75\end{array}$ & $\begin{array}{c}37.91 \\
0.54 \\
0.25<P<0.50\end{array}$ \\
\hline $\begin{array}{l}\text { Heterogeneity } \chi^{2} \\
\text { P value }\end{array}$ & $\begin{array}{c}10.23 \\
0.50<\mathrm{P}<0.75\end{array}$ & $\begin{aligned} 5.58 \\
0.95<\mathrm{P}<0.975\end{aligned}$ & $\begin{array}{c}12.88 \\
0.50<\mathrm{P}<0.75\end{array}$ & $\begin{array}{c}37.37 \\
0.01<\mathrm{P}<0.025\end{array}$ \\
\hline
\end{tabular}

Table 3. Chi-square tests for goodness-of-fit to a 2:1 ratio for the distributions of segregating and nonsegregating $F_{3}$ families from dominant $F_{2}$ plants.

\begin{tabular}{|c|c|c|c|c|}
\hline \multirow[b]{2}{*}{ Mutant character } & \multicolumn{2}{|c|}{$F_{3}$ families observed } & \multirow[b]{2}{*}{ Chi-square } & \multirow[b]{2}{*}{$P$ value } \\
\hline & Segregating & Nonsegregating & & \\
\hline $\begin{array}{l}\text { Short-internode dwarf } \\
\text { Curled leaf }\end{array}$ & $\begin{array}{l}15 \\
14\end{array}$ & $\begin{array}{l}5 \\
6\end{array}$ & $\begin{array}{l}0.63 \\
0.10\end{array}$ & $\begin{array}{l}0.25<\mathrm{P}<0.50 \\
0.75<\mathrm{P}<0.90\end{array}$ \\
\hline Multifoliolate leaf & 17 & 3 & 3.03 & $0.05<P<0.10$ \\
\hline Cotyledonary branching & 23 & 15 & 0.64 & $0.25<P<0.50$ \\
\hline
\end{tabular}


tively. The short-internode dwarf character differs phenotypically from other dwarf characters which have been reported in $M$. alba $(1,2,4,5)$, but it is similar to these other dwarfs in its monogenic recessive inheritance.

\section{Curled Leaf}

Crosses between the curled leaf mutant and normal plants were successful when the mutant was used as the male parent. Three $F_{1}$ plants were obtained from this cross, and all were normal in morphology and seed set. Plants in the $F_{2}$ generation were readily classified as either normal or curled leaf; no other phenotypes were found. The observed $F_{2}$ and $F_{3}$ frequencies of normal and mutant plants agreed well with a 3:1 ratio (Tables 1 and 2). Among the progenies of phenotypically normal $F_{2}$ plants, a ratio of approximately two segregating families to one nonsegregating family was observed (Table 3). Plants grown from selfed seed of four curled leaf $F_{2}$ plants were all mutant in phenotype. Evidently the curled leaf character, like the short-internode dwarf, is recessive and monogenic. The designation proposed for the curled leaf allelic pair is $\mathrm{Cl} / \mathrm{cl}$.

\section{Multifoliolate Leaf}

Attempts to use multifoliolate leaf plants as the female parent in crosses with normal plants were unsuccessful. Five $F_{1}$ seeds obtained from the cross, normal $\times$ mutant, produced multifoliolate plants, suggesting that the mutant character is dominant. Progenies of three of the five $F_{1}$ plants segregated for a leaf mottling character as well as for multifoliolate leaves. Progenies of the other two $F_{1}$ plants, which appeared to segregate only for the multifoliolate character, were used in further studies. Seed set on these two plants was less than half the normal level; thus the $\mathrm{F}_{2}$ numbers are relatively small (Table 1). Nevertheless, a good fit to the expected ratio of three mutant to one normal was obtained. Similarly a ratio of approximately $3: 1$ was observed for the mutant and normal individuals in segregating $\mathrm{F}_{3}$ families (Table 2). The ratio of segregating to nonsegregating $\mathrm{F}_{3}$ families from multifoliolate $\mathrm{F}_{2}$ plants was higher than expected, but the $\chi^{2}$ value was not significant at the 0.05 probability level (Table 3 ). $\quad F_{3}$ progenies from normal $F_{2}$ plants were uniformly normal in phenotype.

All available evidence supports the conclusion that the multifoliolate character is controlled by one gene pair, and that the mutant phenotype is dominant over the normal trifoliolate condition. The designation $M f / m f$ is proposed for this allelic pair. Reports of other $M$. alba mutants resembling this one have not been found. However, Bingham (E. T. Bingham, 1965. Inheritance of multifoliolate leaves in diploid alfalfa. Agron. Abstr. p. 8) reported that a recessive gene is responsible for a multifoliolate mutant of diploid Medicago sativa $L$., with two additive genes influencing the variability of expression.

\section{Cotyledonary Branching}

A single $F_{1}$ plant, intermediate in phenotype between the two parents, was obtained from a cross of branched $X$ normal. No branches arose from the cotyledonary axils, but branch formation did occur in several of the higher leaf axils. In the $F_{2}$ generation, plants were classified into three categories: normal, intermediate, and branched. The intermediate class included plants whose branching resembled that of the $F_{1}$, as well as some plants which had poorly developed branches arising from the cotyledonary node. Accurate assignment of very young $F_{2}$ plants to the three classes was not possible, but classification was readily accomplished after the plants had reached an age of about 4 weeks. The $\mathrm{F}_{2}$ distribution, 26 normal:49 intermediate:28 branched, suggested a $1: 2: 1$ ratio. This distribution, together with the intermediate phenotype of the $\mathrm{F}_{1}$, prompted speculation that intermediate plants might be heterozygous. However, $F_{3}$ results failed to verify this speculation. Of six $F_{3}$ families from normal $F_{2}$ plants, four bred true for normal and two segregated. Among $32 \mathrm{~F}_{3}$ families from intermediate $F_{2}$ plants, 21 segregated and 11 were completely normal. Considering the $38 \mathrm{~F}_{3}$ families from normal and intermediate $\mathrm{F}_{2}$ plants together, 23 segregated and 15 did not, providing a reasonably good fit to a 2:1 ratio (Table 3).

Clearly the normal and intermediate $F_{2}$ classes could not be reliably classified as homozygous and heterozygous genotypes, respectively. Consequently the normal and intermediate classes were combined in the "normal" category in the $\mathbf{F}_{2}$ (Table 1), and no attempt was made to distinguish between normal and intermediate in the $\mathrm{F}_{3}$. Only branched plants were observed in six $F_{3}$ families from branched $F_{2}$ plants.

The $\mathrm{F}_{2}$ ratio of normal to branched is close to $3: 1$ (Table 1) as is the ratio based on the 23 segregating $\mathrm{F}_{3}$ families (Table 2). However, the heterogeneity $\chi^{2}$ value exceeds that representing the 0.05 probability level. One of the $F_{3}$ families included 16 normal and 15 branched individuals. This family contributed 9.04 to the sum (37.91) of $\chi^{2}$ values for all $F_{3}$ families. Except for this family, the $\chi^{2}$ value based on pooled data would have been $0.015(0.90<\mathrm{P}<0.95)$, and the heterogeneity $\chi^{2}$ would have been $28.86(0.10<\mathrm{P}<0.25)$.

On the basis of the available data, it is reasonable to postulate that the branched character is recessive and is governed by one major gene pair. The designation $C b / c b$ is proposed for this pair of alleles. The lack of uniformity among the $F_{2}$ plants carrying the $C b$ allele might have resulted from interaction of this allele with other genes introduced from the branched parent. However, no definite evidence was obtained on this point.

\section{Future Use of Mutants}

All four of the mutant strains described in this report have good plant vigor and adequate seed production for line maintenance. Also, each of the mutant phenotypes is readily distinguished from normal. Because of these attributes, the four mutants hold much promise for further use in genetic studies in M. alba. The mutant strains also might be used in biochemical investigations. In particular, the short-internode dwarf and cotyledonary branching mutants might be useful in studies of growth-regulating compounds in Melilotus. 


\section{LITERATURE CITED}

1. Clarke, A. E. 1931. Inheritance of the dwarf branching habit in sweet clover. Sci. Agr. 11:326-332.

2. Elders, A. T. 1928. A dwarfing character in sweet clover. Sci. Agr. 8:438-440.

3. Goplen, B. P. 1967. A recessive pleiotropic gene conditioning unifoliolate leaves and cauliflower inflorescences in sweetclover. Can. J. Genet. Cytol. 9:136-140.

4. Hartwig, E. E. 1942. Inheritance of growth habit, cotyledon color, and cup-leaf in Melilotus alba. J. Amer. Soc. Agron. 34:160-166.

5. Kirk, L. E. 1931. Inheritance of dwarf branching habit in a new variety of sweet clover and its potential economic value in breeding. Sci. Agr. 11:315-325.
6. Kleinhofs, A., H. J. Gorz, and F. A. Haskins. 1968. Mutation induction in Melilotus alba annua by chemical mutagens. Crop Sci. 8:631-632.

7. Micke, A. 1958. Mutationszüchtung beim weissen Steinklee (Melilotus albus) mit Hilfe von Röntgenstrahlen. Z. Pflanzenzücht. 39:419-437.

8. Scheibe, A., and G. Hülsmann. 1958. Mutationsauslösing durch Chemikalien beim Steinklee (Melilotus albus). Z Pflanzenzücht. 39:299-324.

9. Scheibe, A., and A. Micke. 1967. Experimentally induced mutations in leguminous forage plants and their agronomic value. Abhandlungen der Deutschen Akademie der Wissenschaften zu Berlin (Klasse für Medizin) Nr. 2:231-236.

10. Smith, W. K., and H. J. Gorz. 1965. Sweetclover improvement. Advance. Agron. 17:163-231. 